\title{
Our Friends: Loyalty and Competition in the Canadian Liner Trades, 1853-1913
}

\section{Kenneth Mackenzie}

L'évolution des relations entre les compagnies de navigation à vapeur et le gouvernement du Canada au cours de la période 1853-1913 a déterminé l'avenir de la marine marchande canadienne. Les compagnies qui offraient un service de bateau à vapeur régulier se sont tournées vers les subventions gouvernementales, en particulier pour le transport du courrier, afin de compenser les coûts élevés d'investissement et d'exploitation. Par contre, les gouvernements et les compagnies maritimes s'entendaient rarement sur l'objet d'une subvention, que ce soit un avantage politique régional ou le soutien d'un service, ou même sur la façon dont elle devrait être utilisée, comme paiement initial avec financement supplémentaire ou soutien d'un service actuel. Il en a résulté un conflit politique constant, que l'on examine ici.

This paper offers my initial conclusions on the topic of steamship services to Canada up to the First World War. ${ }^{1}$ This leads naturally to an exposition of what I perceive to have been the factors that brought Canada's merchant marine to its present status. There are gaps in the story, and incomplete research, some of which I note.

In the course of my research into marine history I have been astonished at the frequency with which the phrase "our friends" has cropped up. As intriguing is the range of connotations put on it by those using it. When indeed it was used to denote real friendship (and these occasions were relatively rare) and hence cooperation, it was generally used by the maritime fraternity itself. We shall see examples of this throughout the period under consideration. On the other hand, in the usage of

\footnotetext{
1 This paper was presented at the 1984 CNRS conference in Kingston, Ontario. It was selected for printed distribution in the society's Canada's Atlantic Connection.
}

The Northern Mariner / Le marin du nord, XXIX, No. 4 (Winter 2019), 359-374 
opponents or protagonists it was but a sarcastic comment. To government officials, swept up in the terminology of the business if not fully alive to its aspirations, it was generally employed to denote frustration at the devious ways of shipowners. In following the phrase through this period I will show the interaction of government and shipowners in Canada, and thus indicate the rise and fall of our merchant marine in the age of steam. As I think you will see, the subtitle could have been "Faith, Hope and Charity"!

One other preface is necessary, and that is that throughout the paper I will basically ignore the British and American Royal Mail Steam Navigation Company, better known as the Cunard Line. The correct title was the long one, for Cunard never was a Canadian line, operating for Canadian purposes. He fully admitted this fact, ${ }^{2}$ and it was a bitterly recognized reality in central Canada.

Quite naturally the first call for "fair and liberal consideration"3 for a hardpressed shipowner came from the operator of the first steamship line to Canada (that is to say, Upper and Lower Canada), Robert Lamont. His company had just signed a lengthy contract for the carriage of the Canadian mails across the Atlantic, and he wished to renegotiate payment under what, to him, was the accepted way of life in such matters. As he told the Canadian politician responsible for the contract he was "only following what seems the necessary or natural law of such matters". 4

This somewhat cynical approach to the flexibility of signed contracts did not faze the Canadians. They ignored Lamont's request - bolstered, one might presume, by the fact they had already picked a successor to Lamont's line. This was the brand-new, untried Canadian line of Hugh Allan, the Montreal Ocean Steam Ship Company. Only when Allan proved a trifle too canny and indicated a preference to cooperate with Lamont in providing a service to Canada did the government relent. Allan later wrote that "it was the anxious wish of the Government that the Canadian Steam Navigation Company should be associated with me in any new contract which might be entered into"5 but to this historian it is obvious that the anxiety was Allan's, who was by no means convinced he could make a financial success of the venture. Allan had dictated the terms of the contract that the government proffered and it is safe to assume he had dictated this wish too.

Be that as it may the Lamont firm did not participate again, although it departed with protestations of good faith ringing in its ears. The local press tried to impress upon its readers that "strictest faith has been and should be kept with the English contractors," an opinion Lamont et al. would not have echoed. In

\footnotetext{
2 Cunard deposition to the British Select Committee on Post and Telegraphic Contracts, 23 March 1860, 204, Archive of the General Post Office, London, UK.

3 Lamont to Chief Commissioner of Public Works, 23 January 1855, quoted in Canada, House of Commons, Sessional Papers, 18 Vict. 1855, App. C.C.C.

4 Ibid. Those interested in more details on this interesting episode are referred to my various writings on the subject, a listing of which will be provided upon request.

5 Allan to Chief Commissioner of Public Works, 11 June 1855, Library and Archives Canada (LAC), Ottawa, RG11, vol 23.

6 Quebec Gazette, 5 January 1854.
} 
fact, they argued, and with some degree of accuracy, that they had been unfairly treated.

When Allan reached Britain after being offered the contract he found it remarkably easy to attract the capital he required, and William Denny \& Sons, shipbuilders, quickly signed a contract with "you and your friends in this country" to build the two additional steamers he required. Allan then only went through the motions of obtaining Lamont's cooperation.

Allan was in business, but he was most anxious about his venture. His cable for additional aid, with its clarion call of pending doom, reached Ottawa

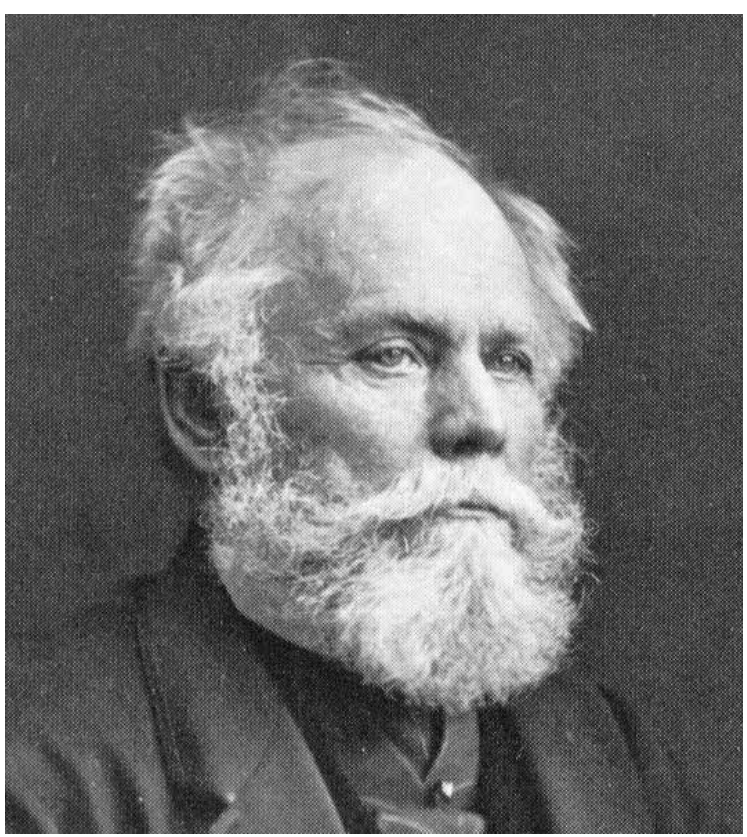

Sir Hugh Allan (Library and Archives Canada) on the same day in June 1856 that the North American, his first scheduled mail steamer, sent her line across to the jetty at Quebec City. In fact the Canadian government had struck a sharp bargain with Allan, decreasing the subsidy he had expected by 50 percent. Allan was many years before feeling that his entry into the prestigious field of carrying the mails was indeed a good decision. Nevertheless he was to fight tooth and nail to retain it for the next fifty years.

Allan immediately made the same calls for increased payments as had Lamont the previous years, using the same argument. After three years of importunations, replete with forecasts of disaster, he did indeed convince the government that without additional assistance his line would fail. In what must rank as the most friendly act of all done to a steamship company in Canada the Canadian government, in 1860, passed "An Act to Grant Additional Aid to the Canadian Line of Steamers." The act was specifically "to enable the proprietors of the ... Line ... to provide additional vessels of greater power and size, and of a better class, than those hitherto employed, and to perform more surely the services required of them in the maintenance of a weekly line of postal communication."8 This act represents the only time I have seen of a Canadian government providing assistance for the increased development of a steamship company.

Of course Allan tried to parlay this into even greater monetary concessions, so

7 Wm. A. Denny \& Bros, to Hugh Allan, 9 May 1855, in Allan to Chief Commissioner of Public Works, 1 June 1855, LAC, RG 11, vol 23.

8 Canada, Statutes, 23 Vict. 1860, c. 5. 
much so that in late 1859 the Canadian minister of Finance, his fellow Scot, A.T. Galt, was forced to bring him up short and to remind him that there were other calls on the colony's revenue. To a ministerial colleague Galt later confided that Allan and his friends were "a "mean lot"" and warned him that "now they have got the new subsidy - you will find them rather unmanageable." Nevertheless the overt friendship still had some months to run. Only when the safety records of Allan's ships reached a dismal low and brought into disrepute both his line and the entire St Lawrence route did the government react.

The downturn when it occurred was dramatic - and it happened even before Allan's ship losses reached their worst point. Only a year after offering Hugh Allan the inducements of the assistance act to double his commitment to the mail route, the government, led by John A. Macdonald, showed its utter disregard for his efforts. It was a complicated matter not helped by the fact that it failed, ${ }^{10}$ but simply put it amounted to Macdonald offering a "ready-made flotilla" to the British government in return for an imperial-subsidized British North American mail service. This flotilla was in fact Allan's mail ships, and in return he suggested imperial considerations in other areas of Canadian interest, most notably militia and railway affairs. ${ }^{11}$ Not for the last time were the interests of shipping companies to be subordinated to those of railways.

Ready-made the fleetmay have been, but it had been built labouriously, painfully, expensively, by the unremitting toil and anguish of the Allans. Macdonald may have had a certain right to feel a proprietary interest in the Allan Line: payments to it under contract had totalled almost exactly the entire monetary investment in ships and facilities by the owners (three million dollars in rough figures). Nevertheless it was Allan's line, and it was the only regular mail steamship company serving Canadian needs. Nothing could have been more indicative of the way in which the Canadian government approached the idea of a national-flag merchant marine.

By 1863 dissatisfaction with the Allan service was so widespread that the contract was cancelled and calls sent out for a replacement. When none was forthcoming the postmaster general was forced to go to Council to recommend a return to the presumably contrite and chastized Hugh Allan, "whose considerable courage, energy, perseverance and ability" had rendered him deserving of a second chance - or so he reported. However, in his report the postmaster general hastened to add, with an obvious feeling of accomplishment, that in accepting the new contract "we shall be abandoning the system of bounties as relates to the route."12

And so they did. From that time dates the Canadian government's laissez faire

9 Galt to Allan, 16 November 1855, LAC, minister of Finance letter books, "Private", RG19-El(a), file 3376, and to Postmaster General Smith, 5 May 1860, LAC, MG27-1-D8/2, pp. 50205.

10 For a fuller discussion of this see my article, "A Ready-Made Flotilla: Canada and the Galway Line Contract 1859-1863," The Mariner's Mirror 74:3 (August 1988).

11 Macdonald to Smith, 21 August 1861, LAC, Sidney Smith Papers, MG24 B63, 67-71.

12 Postmaster general to Council, 7 December 1863, in Canada, House of Commons, Sessional Papers, No. 28, 27 Vict. 1864. 
policy towards a merchant marine. The only question that remains unanswered was whether or not it represented a philosophical or a pragmatic choice.

The confidence expressed in Hugh Allan, (the expression of which was aided by the tacit admission by the government that it shared the blame for his poor safety record), proved to be well-placed. His line was destined to become a force on the North Atlantic for decades, although increasingly over the years it was to become obvious that the capital necessary to maintain its premier position simply was not forthcoming from Canadian sources.

The postmaster general had boasted that the government was acting in the interest of unfettered competition in reducing Allan's subsidy, but the plain fact was there was as yet none, or next-to-none, on the Canadian route. There were very few public complaints as to the fact of supporting a mail line (although there was more than a few critical of Allan himself), and there is only one official complaint on record - the representative of the Anchor Line complained, a year after its organization in 1859 , that the contract was unnecessary. ${ }^{13}$ Unfortunately we can only conjecture as to what happened in the industry immediately following this period, but in very short order the Anchor and Allan Lines seem to have operated in harmony on the St. Lawerence-to-Glasgow run. The Anchor Line was a Scottish firm based in Glasgow, and the Allan's best friends, their relations in fact, were also based in that Scottish city. It is not stretching the imagination too far to assume the two firms came to some sort of agreement to reduce or throw out competition on the route. Canadian shippers soon came to chafe at the Allan control over the route.

Action and reaction in 1873 helps to confirm the educated guess as to mutual arrangements between Anchor and Allan. In this period another steamship company, with real potential to offer serious competition to Allan, appeared on the St Lawrence route. "Having in the spring of ... 1872 ... been urged by influential Canadian friends," we are told, the original British principals of the Liverpool \& Mississippi Steamship Company took a long look at operating their ships to the St Lawrence during summer, when their vessels in the cotton trade to New Orleans were underemployed. "Among many of the foremost men" in Montreal, its agent continued, there was "a strong desire that the Dominion Line should become a strong institution" on the river. Putting money where their mouths were, a subscription list soon resulted in sufficient investment for the original British private company to accept public ownership, as the Mississippi \& Dominion Steamship Line. ${ }^{14}$

Initially only a complementary service to the southern one, it soon became obvious that the best growth was on the St Lawrence. However, even before this could be tested the Allans acted, swiftly and ferociously. The Allan Line placed a vessel on the other's New Orleans route. One trip was sufficient: once again we can assume an agreement was reached.

13 G. \& D. Shaw, Anchor Line agent, petition, 10 March 1860, LAC, RG4-C1/474( 506 ).

14 As published in the Montreal Herald \& Daily Commercial Gazette, 8 July 1873. 


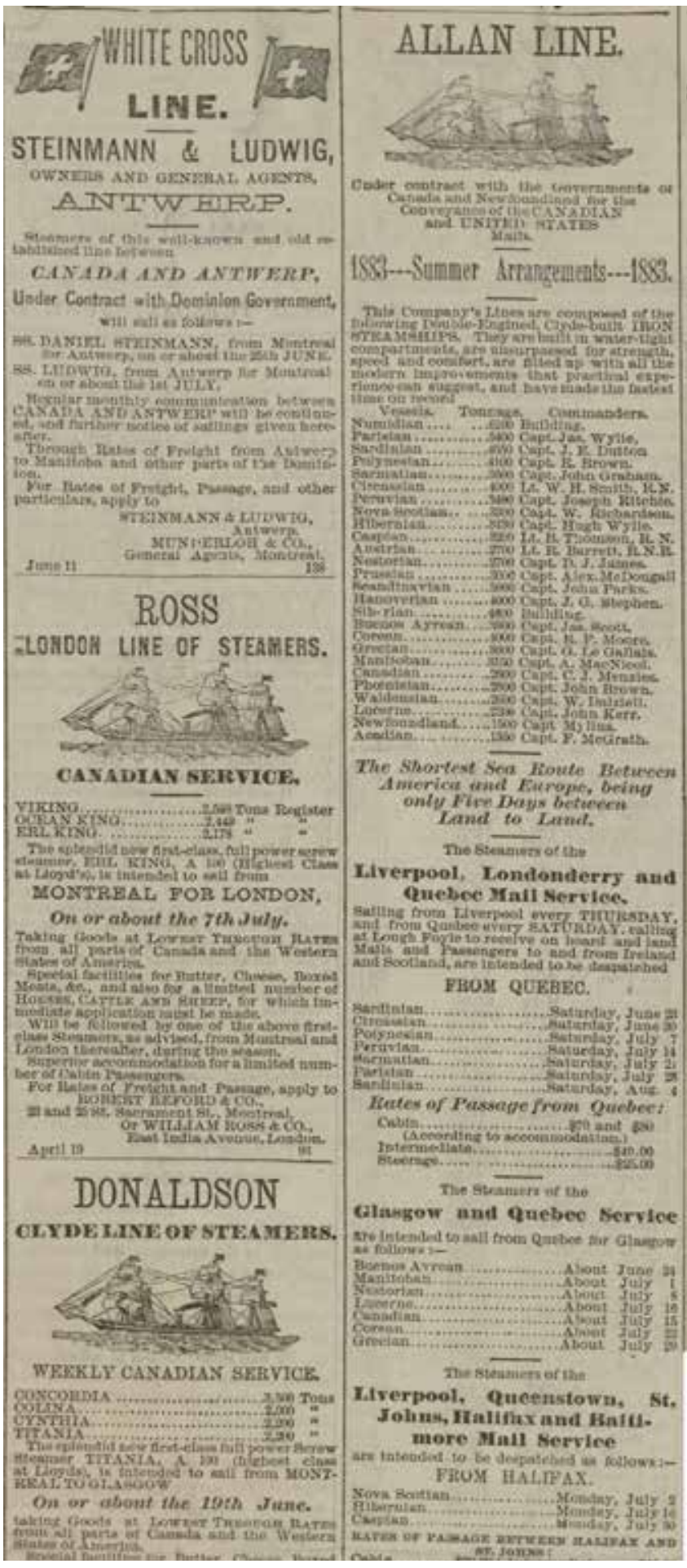

DOMINION LINE. SIIHANASEIPS

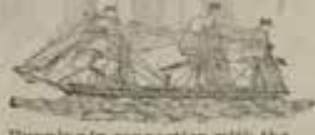

Ririnine in oonnection with the Grund Trunk Railway of Caunds

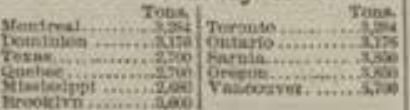
DATES OP BAIHIGG nose gesause in arrancot. Tothos

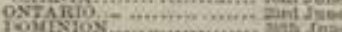

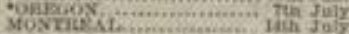

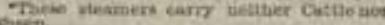

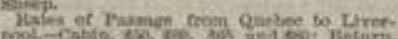

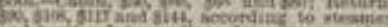

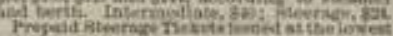

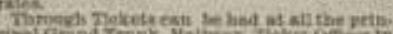

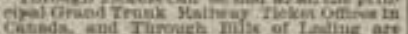

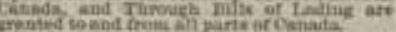

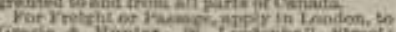

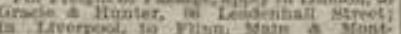

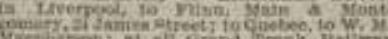

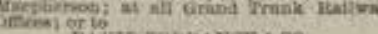
April:

CANADA SHIPPINGCO

Beaver Line of Steamships.

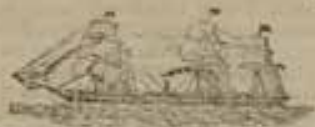

SUMMER ARRANGBMENTS.

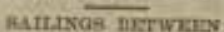

Montronl and Liverpool.

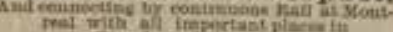

Cancla shat tee Went

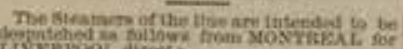

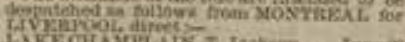

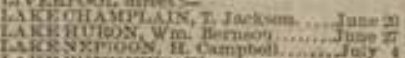

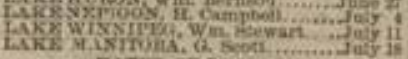

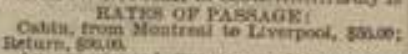

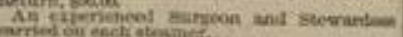

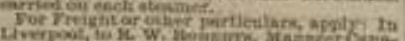

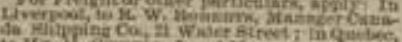

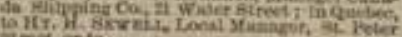
11. $x$ Muntiv.

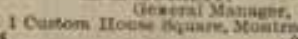

Montreal Herald, 19 June 1883, p. 2 
The Allan Line Mississippi service died a quick death, while the Dominion Line bowed to whatever had been Allan's demands for the North Atlantic route. There is evidence that Hugh Allan conceded the assisted-emigrant trade to it; after 1874 the Dominion Line was the possessor of small dominion government payments for each emigrant brought to Canada. Once the arrangement had been made Allan exhibited no qualms in selling to his quondam opponents a ship to fill out its fleet. As we shall see twenty-five years later this friendship was still very much in effect.

This spirit of cooperation, no matter how slender, was fortuitous, for the federal government exhibited no tendencies to assist steamship companies per se. While the National Policy of 1879 did provide the smallest sop to maritime interests by offering a wide variety of meagre, disconnected trade subsidies in the largely forlorn hope of establishing new markets overseas for Canadian products (there were still very few steamers trading regularly from the St Lawrence to anywhere else but Britain). These subsidies were devised to appeal as much to Canadian regionalism as to attempt honestly to serve Canadian exporters (of which there were precious few anyway). ${ }^{15}$ indeed one did not even need to possess ones own ships to be the successful contender for these subsidies, and shipowners who applied for them were distinctly in the minority. At various times efforts were made to establish routes to a variety of European, West Indian and South American ports (with the odd concession to west coast interests by including similar inducements for trade there).

The most energetic of these efforts between 1880 and 1895, which was probably also the most futile, were those efforts to establish a commercial link between Quebec and France. This was deemed "of so much importance that the line should be established and the trade between the two countries commenced as soon as possible" that Macdonald told his French lieutenant, J.A. Chapleau, that he "would support such a proposition if the enterprise cannot be undertaken on easier terms."16 In reality, however, Macdonald espoused it simply as aid in getting Chapleau elected some months later. Subsequent efforts in this trade were put forward for identical non-commercial reasons. But that is another story! There are many other examples like this, where other regional interests were pandered to, but times does not permit into detail.

There is another side to this story: few Canadians indicated an interest in these routes, and even fewer complained if surprisingly one came to fruition and went to some fly-by-night company either at home or abroad. The Canadian commercial community seems to have been content to let British (and foreign) ships ferry over steel rails for Canadian railways, send timber and grain back, and even allow

15 Examples of complaints abound throughout the record. See also Glen Williams, Not for Export: Toward a Political Economy of Canada's Arrested Industrialization, (Toronto: McClelland \& Stewart, 1983), for a particularly good discussion of this.

16 Macdonald to Chapleau, 30 August, 8 November 1811, LAC, Macdonald Papers, Vol. 204, reel C-1594, C-33. 
Norwegian colliers to obtain a stranglehold on East Coast shipments up the river. Canadian shipowners were not interested in these marginal endeavours.

For fourteen years after the declaration of the National Policy there was no bureaucracy dedicated to handling steamship matters. Had there been an overwhelming response to the various subsidies trotted forward it is intriguing to imagine what might have been the organizational chaos. The deficiency was undoubtedly an indication of the lack of interest in such matters, but it also meant the gradual deterioration of those that did exist. Prior to 1879 steamship subventions had been for mail purposes. As the work became increasingly complex the department became less willing or less able to cope. Some time in 1888 a subcommittee of the Privy Council was established to consider the whole question of "granting subsidies to Steamship Lines for the conveyance of mails and for Commercial Purposes." In its report, submitted in January 1889, after the normal expression of their diligence, the honourable members then delivered themselves of this memorable paragraph: "while desirous of establishing, if possible, some general rules which should regulate in all cases the granting of subsidies to these Lines they find that from the great diversity which exists between the various sections of Canada in geographical position, in comparative population and in commercial interests, that it is impossible to lay down any hard and fast rules upon which the grant or refusal can in all cases be bound." 17

In other words, political considerations were to dominate, particularly those that satisfied regional interests. About the only substantive measure that developed from this committee was that the Department of Finance took over responsibility for the subsidized services. This was apparently not formalized until an order-incouncil of July 1892, and was to prove short-lived, however, as the new Department of Trade \& Commerce fell heir to the task upon its formation in January 1893.

Nothing magical happened in the way of handling subsidies after 1893, and their administration continued to be largely hit or miss. Whereas before we might find cabinet ministers waxing indignant over the way in which their opinion was not sought or was ignored, ${ }^{18}$ thereafter it was more likely to be a bureaucrat ( and often the long-suffering W.G. Parmelee, deputy minister of Trade \& Commerce), venting his spleen with some remarkably frank comments in departmental records. When for example a cabal of maritime ministers conducted all negotiations for a particular service, in delightful isolation from his department, he made his minister, R. I. Cartwright, squirm with embarrassment before the matter was resolved. ${ }^{19}$ When steamship operators were allowed to get away with flagrant and continued

\footnotetext{
17 Report of a Committee of the the Privy Council, approved 25 February 1889," LAC, RG19, vol. 3064, file 4578 .

18 Readers are referred to my article "William Darley Bentley and the Burden of Canadian Unity," The Journal of Transport History 3rd series, 4: 1( March 1983), 31, for Postmaster General Campbell's exasperation with Macdonald.

19 See the delightful exchange of correspondence between Parmelee and Cartwright, 1, 4 September 1899, in LAC, RG20-1189/6374, over a contract negotiated entirely by "the Ministers for the Lower Provinces, Messrs Fielding and Blair."
} 
violations of their contracts, he coined the phrase "go-as-you-please contracts" and the term somehow found its way into the contemporary press. ${ }^{20}$ In fact, the entire system was run without a single unifying policy. Lest you think I overstate a case let me quote from a querulous letter written by an Allan Line agent to the Post Office in 1906 at the end of a series of glorious jurisdictional muddles. "We desire specially to treat with the Department of Trade \& Commerce," he wrote, "because there have been so many changes in connection with this matter that we feel it is necessary to deal with one Department." 21

It is now time to turn our attention to a most intriguing matter - the extent to which Canadians were in fact intimately involved in the steamship trade on the North Atlantic. I have already discounted the Cunard Company, but lest you think that arbitrary act decimated Canadian content, let me elucidate. Many of us have heard of the Allan Line, Cunard's Canadian counterpart. But do we all know that in 1894 the Allan Line was operating thirty-seven ships, aggregating 120,000 tons, and dominating trade routes on the North Atlantic??22 The Dominion Line, which we have already mentioned briefly was almost entirely Canadian-owned when it was bankrupted in 1894/95. Some of us have probably even heard of the Beaver Line. It made its start in 1868 , operating a fleet of iron sailing ships to Canada (besides the Allans the only Canadians so to do?) and then made the transition to steam, albeit hesitatingly. Nevertheless they too managed to survive for almost a quarter of a century in the liner trades. What about the extraordinary three-pronged Canadian Northern Railway fleet - crack mail ships, plodding emigrant carriers, and Great Lakes freighters - with which Mackenzie \& Mann planned their allencompassing competition to the CPR, but which was snuffed out by the First World War?

But how many have heard of the Temperley-Ross Line, a fleet of small freighters which by 1890 was apparently owned by the Ross family at Liverpool and Montreal. They in turn had amalgamated with Ross's King Line some years before. How about the Thomson Line, which re-registered its ships in New Brunswick in 1907, but whose fourteen small ocean-going steamers were by then "all owned by Maritime Provinces people"? ${ }^{23}$ How about the Quebec Steamship Company - about which only a few of you will have heard a word - of which, more below?

By 1895 there was considerable competition in the St Lawrence trade, much of it in liner operations and much owned or controlled by Canadians. This however also marked the end of a prolonged depression, which had the dual result of bringing both the Beaver and Dominion Lines to collapse, and also a surge in interest in others getting into the trade. Even the Allan Line was in trouble -

\footnotetext{
20 See particularly Parmelee to Ellis, 19 November 1897, LAC, RG20-1163/5556.

21 H.\&A. Allan to Postmaster General, 29 April 1907, LAC, RG3-10/10.

22 Henry Fry, The History of North Atlantic Steam Navigation (London: Sampson, Low Marston, 1896), 157.

23 The Morning Chronicle (Quebec), 14 June 1907.
} 
although according to one writer this was as a result of government procrastination rather than any other commercial reality. ${ }^{24}$

In fact 1895 probably marks a turning point in Canadian shipping circles. After this we really find the flight of Canadian capital from owning steamships. The situation of the Dominion Line is instructive. By 1895 it was virtually bankrupt and well on the way to being taken over by a British firm. The Allans were distinctly uneasy with this. In a letter to the government when their strategy backfired and the government seemed interested in bolstering the Dominion Line they explained: "It may not be known to the government that it was entirely of our own notion that we admitted the Dominion Line to a share in the mail service. Their stock was largely held in Canada, among our own friends and customers, and it was to our mutual interest that we should thus join our forces and work together for the common good. We continued this long after the line had become practically insolvent." 25

But, when the Canadian government then decided to mount a rescue operation on the Beaver Line their indignation was complete: "it is manifestly unfair at this late date we should be brought face to face with further opposition to freight both ways, by the presence of a concern in liquidation, but financially supported by the Canadian government." In particular they were incensed that the Beaver Line's freight services seemed destined to receive a larger subsidy than their mail steamers. $^{26}$

And what did the beleaguered Dominion Line think of their arrangement with the Allans? Well, they were decidedly nervous, as we can judge from two letters written a day apart, exhorting the government to determine, in secrecy (or at least without involving the Dominion Line people) exactly what were the Allan Line intentions to them. The information was so he could inform "our Liverpool friends," wrote John Torrance. And why secrecy? Well, "we do not wish to get into trouble with our friends the Messrs Allans." The government was entirely unsympathetic. The deputy minister to whom the plea was addressed was "confined to his house through illness," and the Dominion Line, regardless of its plea, was referred to its erstwhile friends, the Messrs Allan, for their answers! ${ }^{27}$ To the local press the main disappointment about the Dominion Line changes, which it agreed had been "so closely connected with the progress of the Dominion," was that its captains and

\footnotetext{
24 Fry, 157.

25 H. \& A. Allan to postmaster general, 15 June 1895, LAC, RG20-1119/2690. Of course bolstering a weak line to thwart possible strong competition was a standard ploy. See Lord Ismay's comments concerning the Cunard approach to a similar situation in F.E. Hyde, Cunard on the North Atlantic, (London: The Macmillan Press, Ltd., 1975), 101.

26 H.\&A. Allan to Bowell, and a similar letter from the subservient Torrances, of the Dominion Line, 12 November 1895, LAC, RG20-1127/3211.

27 The correspondence covers 21-23 January 1895, in LAC, RG3-4/21, no. 9158. The previous year the sanctity of the deputy postmaster general's home had been insufficient to restrain the irate Allan, who had burst in on the incumbent in a rage when he learned of the termination of the Allan Line mail contract.
} 
crews would no longer be seen in the area. ${ }^{28}$

Almost symbolically, control of the Allan Line temporarily switched to Britain at this time, with the Montreal partners continually pleading for "our friends in Britain," particularly when the Canadian government tried to enforce nationalistic policies. ${ }^{29}$ As the years progressed and old firms slowly dissipated, loyalty came increasingly to be argued as a substitute for good service. When the reconstituted Beaver Line, under totally new management, applied for a share of the mail contract in 1897, that was the basis upon which its agent appealed. He thought it "well to mention to you that we were the first Company to offer to run a line of steamers during the winter season to a Canadian port and to build up a winter trade out of the port of St. John." 30 This refrain was taken up by a British shipping journal, when discussing the fast Atlantic fiasco: "as it is, the Canadian government stand guilty of ineptitude and shuffling over the fast mail service; ingratitude to the Beaver Line, who played the part of need with regard to the Saint John service and the mails." 31 Thereafter relations between the government and shipping companies seemed to deteriorate, with government officials being increasingly critical of the reliability of shipowners. ${ }^{32}$

The whole question of subsidies came seriously to be questioned. In a fit of petulance the deputy minister of Trade \& Commerce wrote to one agent that "in fact it is a matter of serious consideration whether all these subsidies should not be withdrawn," ${ }^{33}$ a response that caused great worry. Then, as those writing to government concerning aid became more and more agents for overseas owners, and the delay in obtaining operating decisions and information became ever longer, frustration developed. This was the case even in such an organization as the Furness Line, which could not decide on what to call one of its new branch lines. It eventually became the Manchester Line.

Ten years later the subsidy system was still firmly in place, and the bureaucrats at least were no more certain of its efficacy. In 1909 about one and a half million dollars were shared between twenty-two oceanic lines and a host of domestic, and the deputy minister's annual report damned the practice with the faintest of praise: "It is difficult, as a general rule, to gauge the value of the steamship subsidies paid by this Department, but in some instances they show decided and definite

\footnotetext{
28 The Morning Chronicle, Quebec, 20 February 1895.

29 Such as a Canadian winter port for subsidized steamers.

30 Campbell to Parmelee, 20 Ocotber1897, LAC, RG20-1151/4926.

31 The Morning Chronicle (Quebec), 6 December 1898, quoting the British Syren \& Shipping, n.d. about the abortive efforts of the Canadian government to establish a fast mail service that would match Cunard's. Between 1905 and 1914 Allan tried but it was too much. The CPR "Empress" service would eventually become competitive.

32 See Cartwright to Laurier, 25 September 1900. LAC, Laurier Papers, reel C-779, pp. 49552-4, and 9 August 1902, ibid. reel C-795, p. 66969. In the former it was Torrance and the Allans who had "behaved very badly." While in the latter the object of the minister of Trade \& Commerce's disaffection had been Furness, Elder Dempster and the Allans again, "Not one" of which, he reported, had "lived up to their contracts or tried to do so." However, he did not recommend any remedies.

33 Parmelee to R. Reford, shipping agent, 14 June 1899, LAC, RG20-1178/6046.
} 
encouragements." ${ }^{34}$ In a similar vein, if I may be permitted an anachronism, a careful study in 1930 of the value to the CNR of possessing a captive shipping line persuaded that company it was not worth the cost; its writer estimated that the net value to the CNR of its lines was only about five percent of the freight carried..$^{35}$

We come now to the time where my research is still sketchy, and to a situation that makes Canadians apprehensive even today - the influence of external factors on the domestic economy. The turn of the century witnessed an enormous accretion of shipping lines in a very few hands. The most vivid illustration of this was the giant International Mercantile Marine Company - Morgan's combine - put together by the American financier J. P. Morgan. This was soon copied, in style and in substance, by Owen Cosby Philipps in England with the Royal Mail Steam Packet Group. In the American case informed insiders later considered the IMM Combine to have been effectively bankrupt within eighteen months, ${ }^{36}$ although it staggered along until after the war before expiring. Its importance, however, was strictly psychological. The British example was almost as sordid. Philipps built an empire of ships that at its peak made up fifteen percent of the entire British merchant marine. It collapsed during the great depression. ${ }^{37}$ The main purpose of Philipps and Morgan was the manipulation of capital. In neither case did they interest themselves unduly in running a steamship company per se. As a result steamship services suffered. The British merchant marine had to be rescued by its government, thus staying its execution by some fifty years, while the American result was to guarantee the end of the US merchant marine.

There were two much more successful mergers - and these were built on the Canadian experience. Much more secretive, and much more effective, they have been largely ignored. First of these was the CPR. After almost twenty years of dabbling its rails in the Atlantic, in 1903 it obtained, a beach-head, in the now-inept Beaver Line. In 1909 it carried out its master coup, the purchase of the Allan Line. With these acquisitions the CPR became the most complete transportation system in the world, literally encircling it. From my point-of-view, however, the most intriguing aspect of this at the moment is the fact that control of the Allan Line had swung back to Canada just prior to the consummation of the deal. In other words

34 Canada, Sessional Papers, 8-9 Edward VII, 1909, "Report of the Deputy Minister of Trade \& Commerce for the year ended 31 March 1909," xli. The encouraging trade was with Mexico.

35 S.W. Fairweather study, "Ocean Carriers \& the CNR", the results of which he paraphrased very briefly in the "Royal Commission, Royal Commission to Inquire into Railways and Transportation in Canada," House of Commons, Sessional Papers 108-1932/1933, 839-40. Regrettably, the original study cannot now be located.

36 L.F. Loree comment to the Duff Commission in 1932 (Royal Commission on Railways \& Transportation, 4: 21121). Loree was one of the most prominent railwaymen in the United States, and continued in this exchange with Sir Joseph Flavelle that "I have sort of lost confidence in mergers as being of much advantage in matters of economy."

37 See Edwin Green and Michael Moss, A Business of National Importance: The Royal Mail Shipping Group 1902-1937 (London: Methuen, 1982), which gives a chilling account of Philipps' efforts. For a magnificent biography of J.P. Morgan see Jean Strouse, Morgan:American Financier, (New York: Random House,1999), Chapter 23, "Community of Interest," 457 - 484. 


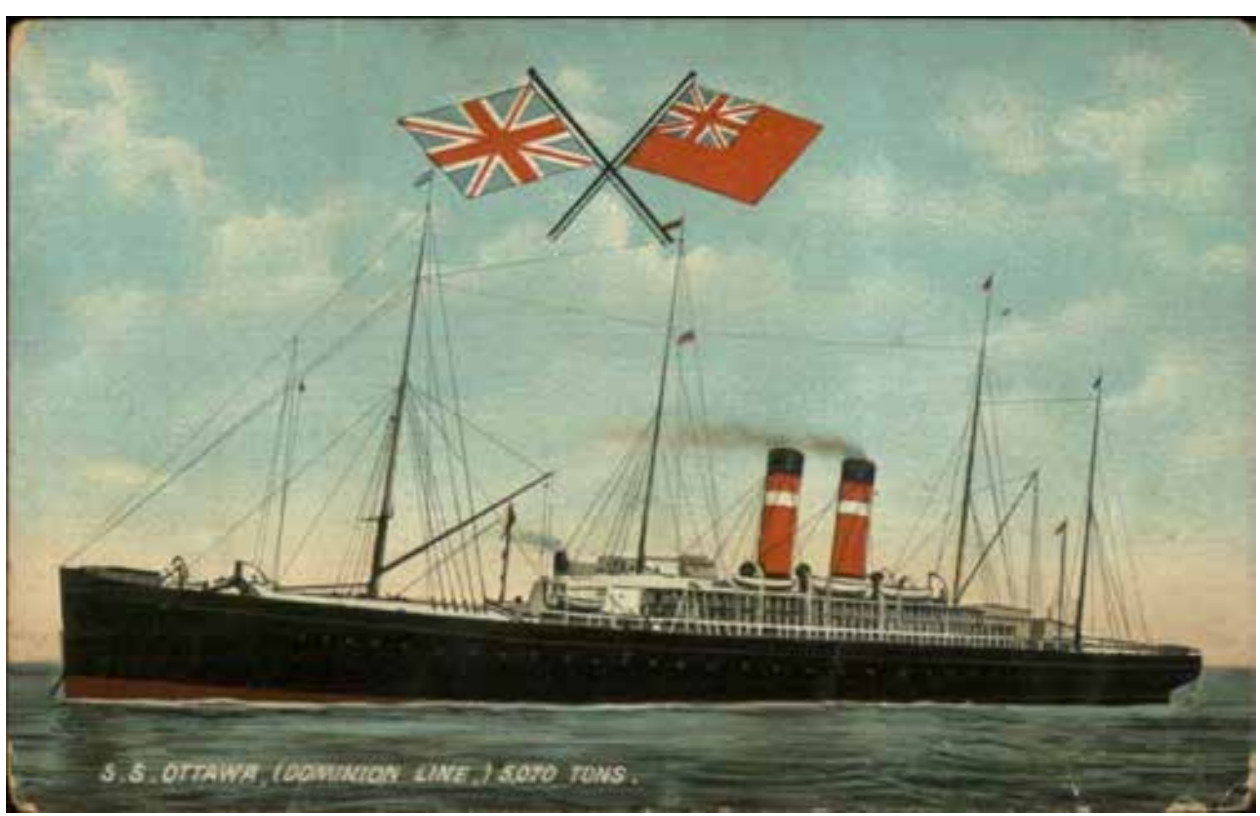

it can be concluded that the Allan Line sell-out was a made-in-Canada deal. But more of that later.

At the same time Canadian inland steam navigation companies were being gradually bought up. This came to fruition in 1913 with the naming of the new company - the Canadian Steamship Lines. For some years the money backing this was from the British Maritime Trust, operated by the Furness family of Britain. That too is another story!

That was a somewhat lengthy introduction to the special case of the Quebec Steamship Company. The Quebec \& Gulf Ports Steamship Company was formed by a group of Quebec City retailers with one motivation - to sell their products in the Lower Provinces. They took full recognizance of the ecstasy of Confederation and incorporated four months in advance, and obtained a subsidy to boot. In those days there was no easy connecting link between central and maritime Canada except through the United States.

No two subscribers owned more than twenty shares at its founding, and there were at least 160 shareholders at its incorporation. It responded to an invitation to tender for a Lower Ports service (that is from Quebec City to Pictou, NS, via intermediate ports) and was the only firm of three so invited actually to submit a tender. Though its shareholders were influential businessmen, there appears only to have been one overt politician, the infamous Thomas McGreevy.

Probably to the surprise of the shareholders the line flourished from the outset. In this it was aided in no small measure by payments under the contract which, over the ten years it was in effect, very closely approximated the capital expended on steamships, about $\$ 200,000$ - much as Allan's ships had been paid for by government money. By 1873 the line was operating five vessels on the Lower St Lawrence and was the toast of the local shipping pages. However, recognizing the 
dangers lurking in the wings posed by the then-building Intercolonial Railway the directors looked further afield to the time when that railway would overcome all political chicanery and operate, and they would have to obtain other employment for their ships. In that year an abortive attempt was made to open up a route to Newfoundland. In the two years before 1876 the company fought off successful competition from two of the most powerful and competitive shipping interests in central Canada, the Ross's and the Allans. By 1876 the Quebec Steamship Company was dominant on the Lower St Lawrence River.

Then came the dreaded opening of the ICR all the way to Halifax. Granted concessional through rates allowing it to tap the entire trade of the west in conjunction with the Grand Trunk Railway, at the connivance of the government, its trade was decimated. After a bitter complaint to the Quebec Board of Trade (which nearly did not even grant it a hearing) and an unsuccessful interview the then minister of Public Works ( who was also the prime minister), of which there is now no record, the company gave up its efforts to change the situation in Canada. There is no record thereafter that its directors, except in the most desultory fashion, attempted to obtain federal assistance in any form. Similarly, when the government was planning many of its new routes over the next four decades, it paid no attention to the one line that had had success outside the traditional routes to Britain and later to Northern Europe.

The 1873 Newfoundland fiasco had convinced the company to look even further afield. Thanks to a connection with the far-flung Outerbridge clan of St. John's [Newfoundland], Bermuda and New York the company, at the urging of the latter representative, was the successful contender for a Bermuda government subsidy for the New York-Bermuda mail service. This commenced in 1874 and was the beginning of a connection that was to remain unbroken until the First World War. The company brought Bermuda into being as a tourist haven. In the course of this activity it obtained a monopoly position and became the dominant factor in the Bermudian economy.

During 1876 and 1877 the company made its last efforts to establish a North American service. It toyed with the coal trade from Nova Scotia to central Canada, and entered the coastal trade, with its ships ranging as far afield as New York and St. John's. It was to no avail, however. When, at the end of 1877 an opportunity arose for yet another mail contract, this time between New York and Venezuela, the directors jumped at it. By the following year an American reporter bore eloquent testimony to the way in which the company had bested US competition. ${ }^{38}$ Although two years later this contract became a victim of one of the local revolutions the company had by then obtained sufficient experience to adjust and to operate profitably throughout the entire Caribbean and adjacent South American coast, as far south as British Guiana. In 1880 it accepted reality and changed its name to the more prosaic but less accurate Quebec Steamship Company.

\footnotetext{
38 See the article quoted in The Royal Gazette (Bermuda), 27 August 1878.
} 
In 1889 the Canadian government tendered for a mail service to the West Indies, but the Quebec Steamship Company, although expressing a vague interest, did not tender. Neither did its name appear in discussion papers when the whole matter was being considered at great length. This contract eventually went to the Halifax firm of Pickford \& Black, which at that time possessed no vessels of its own. But they were good friends of Sir John A.

The company did not need a subsidy. By 1898 the Canadian press claimed it was paramount in the New York-Caribbean service, and went further, proudly averring it was the finest steamship line owned and operated in North America. ${ }^{39}$ It was the only North American-owned company considered by the imperial government when it came to consider rationalization of steamship services to the economically-ravaged British West Indies.

Nothing came of this British initiative, but one episode of it was instructive. Not only did the Canadian government not consider the company, it actively opposed its participation to Joseph Chamberlain then secretary of state for the colonies. Instead, the Canadians espoused the cause of the faltering Pickford \& Black service, by then almost a by-word for inefficiency in the area served by the proposed contract. Yet nowhere in the official Canadian record is there to be found a word of complaint over either the omission or the commission of sin against it. Later a tentative query from the company's secretary as to the termination date of the Pickford \& Black contract elicited the mildly encouraging news that it was soon due for renewal; but they did not make application for it. In reading the various letters between 1889 and 1899 it becomes obvious that the directors only real concern was to ensure that no Canadian contract steamers be allowed to call at an American port to top off cargoes.

The reason for this was simple, if very hard to quantify. Most of the freight its ships carried to Bermuda and to the West Indies was said to originate in Canada, after getting to New York overland. There was no commercial reason for the ships to steam the extra hundreds of miles to Canada: they already had most of the Canadian freight that was likely to be offered. Once the directors were sure that the unfortunate Pickford \& Black were not to be allowed to call at New York or Boston, they were satisfied. Indeed, they even sold them one of their surplus ships.

By 1905 the directors commenced a major upgrading of their fleet, and had indicated an intention to expand the scope of their operations. Two brand-new, impressive ships were ordered, one for Bermuda of 5500 tons, the other of about 4000 for the West Indies. However, between 1906 and 1908, following the death of the company's aggressive President, Pierre Garneau, there was a dramatic change in the personnel of the Board. By 1908 it had been completely turned over. This coincided with the surge in the activities of the RMSP coincident with its battle with the IMM. The RMSP and the Quebec Steamship Company compete in certain West Indies routes, and when, after 1906, the British company indicated it was

\footnotetext{
39 See the two items in The Morning Chronicle (Quebec), 29 January and 15 February 1898.
} 
going to competed in the Bermuda-New York trade that was it. After a one-year expensive rate war the two companies formed a mini-conference in 1910. The tone of the RMSP in response to a suggestion from the Quebec company illustrates the entire matter: "We venture to think that such a course as you have proposed and which we have set out more fully in this letter will be found more satisfactory to you than a renewal of the arrangements which you made last year, and once we have come to an understanding with you we think that you will not find that we are difficult to work with." ${ }^{40}$

More fully indeed! Although the Quebec Steamship Company had purposely omitted the West Indies service from its letter, the RMSP would have none of it, and warned that if its interests there were threatened from any source it would thrust aside the Canadian company as necessary. A year later the Quebec Steamship Company tried to sell itself to the RMSP. After suffering the ignominy of rebuff it then jumped into the arms of the Furness-backed Canadian inland steamship merger, Canada Steamship Lines. Symbolically, the Company's flagship, the 5500-ton Bermudian, sailed from New York under its new houseflag on 13 December 1913, thus closing a remarkably successful yet totally unknown episode in Canadian maritime enterprise.

In the case of the Quebec Steamship Company we have the example of a Canadian firm which, although established to be a captive transportation network for the produce of its shareholders, attracted sufficient enterprise to be able to persevere through some heavy odds for almost fifty years. When the Canadian government turned its back on it in favour of a railway, it simply moved elsewhere, where the same initiative enabled it to take over the New York business. Thereafter it never seriously considered a Canadian subsidy, nor was it sought. An efficient commercial service was only second in the priorities of Canadian politicians. Only when the odds became too great for them did the directors bow out of operating steamships, gracefully and without many (if any) regrets. By then they had better things to do with their money.

The conclusions to be drawn from this are short and sweet - and extraordinarily important. In the first place, Canadians did make the transition to steam and steel, more than sufficient for their own requirement. Second, they chose, more or less in their own time, when to get out of the business and into a more lucrative one. And whatever happened after 1863 it happened without any influence from the Canadian government. Had the Canadian government been any more benevolent to a merchant marine in some way, resulting in its continuance, is purely conjectural. I think not.

\footnotetext{
40 Secretary, RMSP. Co., to Quebec Steamship Company, 27 June 1910, National Maritime
} Museum, Greenwich, RMSP. Papers. 